AUTOR: AlySSON ZANATTA

Orientador: Prof. Dr. Paulo César Serafin

\section{Expressão proteica do gene HOXA10 e dos receptores de estrogênio e progesterona no epitélio, estroma e tecido muscular liso perilesional de endometriose do reto-sigmoide}

\author{
HOXA10 as well as estrogen and progesterone receptor \\ protein expression in the epithelium, stroma, and adjacent \\ smooth muscle of rectosigmoid endometriosis
}

Resumo de Tese

Palavras-chave

Gene HOXA10

Endometriose profunda Endometriose de reto-sigmoide Receptor de estrogênio $\alpha$ Receptor de estrogênio $\beta$ Receptor de progesterona Receptor de progesterona B

Keywords

HOXA10 gene Profound endometriosis Endometriosis of the sigmoid colon-rectum Estrogen receptor $\alpha$ Estrogen receptor $\beta$ Progesterone receptor Progesterone receptor B

DOI: $10.1590 / 50100-7203201410002$
Tese apresentada junto ao Departamento de Ginecologia da Faculdade de Medicina da Universidade de São Paulo (FMUSP), São Paulo/SP, em 23 de julho de 2013.

INTRODUÇÃO: A patogênese da endometriose profunda (EPF) é incerta. O fator de transcrição homeobox A 10 (HOXA 10) regula a conferência de identidade tecidual de útero ao ducto paramesonéfrico indiferenciado. HOXA 10 é expresso em endometriose ovariana, peritoneal, pulmonar e reto-vaginal, relacionando-o à patogênese da endometriose. Estradiol e progesterona ativam a transcrição do gene HOXA10. Nesse estudo, avaliamos a expressão proteica de HOXA10, das isoformas $\alpha(E R-\alpha)$ e $\beta$ (ER- $\beta$ ) dos receptores de estrogênio, e do receptor de progesterona $A B$ (PR-AB) e sua isoforma $B$ (PR-B) na lesão (LES) e no tecido muscular liso perilesional (TMLP) de endometriose de retosigmoide (ERS), durante as fases proliferativa e secretora do ciclo. MÉTODOS: Amostras de LES e TMLP de ERS de 18 pacientes (9 operadas em cada fase) foram agrupadas em blocos de microarranjos de tecidos (tissue microarray). Após preparação imunoistoquímica, avaliamos as amostras por microscopia ótica (MO) e por um software específico, a análise morfométrica (AM). RESULTADOS: HOXA 10 foi expresso no estroma de LES de ERS durante a fase secretora. ER- $\alpha$ e ER- $\beta$ foram expressos em glândulas e estroma de LES e TMLP de ERS durante ambas as fases do ciclo. PR-AB e PR-B foram expressos em glândulas e estroma de LES de ERS durante ambas as fases do ciclo. A expressão de HOXA 10 correlacionou-se diretamente com PR-AB e PR-B na ERS. Não houve correlação entre ER- $\alpha$ e ER- $\beta$ com HOXA10, PR-AB ou PR-B em nenhuma fase do ciclo ou local de expressão de ERS. CONCLUSÕES: HOXA10 é expresso em ERS, fora do seu eixo espacial de expressão. HOXA10 pode ser necessário para conferir a identidade "de novo" na EPF, incluindo ERS, favorecendo a hipótese da origem embrionária da doença. A progesterona pode ativar o gene HOXA 10 e regular esta ação, possivelmente mediada por PR-B. A ação mitógena do estradiol na ERS é mediada por ER- $\alpha$ e ER- $\beta$. 